\title{
Comment on "The End of Phase 3 Clinical Trials in Biosimilars Development?"
}

\author{
Christopher J. Webster ${ }^{1}$. Gillian R. Woollett ${ }^{2}$ (])
}

Published online: 16 August 2018

(c) The Author(s) 2018

\section{Dear Editor,}

We agree with the broad reasoning and conclusions of Dr. Frapaise in his manuscript The End of Phase 3 Clinical Trials in Biosimilars Development? [1], that it is time to evolve the evidentiary basis for approval of most biosimilars away from a requirement for powered clinical efficacy studies and wish to add the following comments to his discussion.

Dr. Frapaise cites the potential opportunity to save development resources as the major benefit of discontinuing large trials. We agree with this conclusion, although his quoted saving of "at least US\$50 million for a 600-patient trial" may be overstated-typically, these studies recruit 200-400 patients per group at a per patient cost of about $\$$ US 44,100 [2], giving a study cost in the range of \$US17.6-35.3 million. These figures accord reasonably well with those found by the Eastern Research Group [3] for the US Department of Health and Human Services. Of course, there are variables within these costs, which may not arise for other types of studies, including the cost of obtaining a sufficient and uniform supply of reference biologic, but we do not believe such costs would inflate the total by more than \$US10 million.

However, we believe an even more significant reason exists to discontinue most of these studies, and that is that they lack scientific validity because their outcome with regard to biosimilarity is not in doubt. Without scientific validity, there is no ethical validity [4]. The insensitivity of the chosen equivalence margins to the relatively minor differences, mostly in post-translational modifications, between

This comment refers to the article available online at https://doi. org/10.1007/s40259-018-0287-0.

Gillian R. Woollett

gwoollett@avalere.com

1 BioApprovals, Acton, MA, USA

2 FDA Strategy and Regulatory Policy, Avalere Health Inc., Washington, DC, USA a biosimilar candidate and its reference that have been shown to be closely similar in earlier studies ${ }^{1}$ means they can be reliably predicted to be equivalent in powered efficacy studies. We are not aware of any exceptions to this rule, with over 40 biosimilars now approved in the EU, applications for 35 of which included clinical efficacy data. Indeed, this accords with the regulatory experience of thousands of comparability evaluations of biologics after manufacturing changes [5], where regulators have very rarely required clinical studies ${ }^{2}$. In addition, others have noted [6] the futility of trying to evaluate the clinical equivalence of biologics when they are just one part of a complex drug regimen.

We contend that this is an issue that should concern regulators, because it is clearly not defensible to require studies that do not contribute new information towards the evaluation of the product. But also, sponsors often conduct comparative efficacy studies because they believe that the data will facilitate marketing to clinicians, yet ultimately this practice undermines the fundamental analytical basis of biosimilarity [7]. While this may have been a reasonable rationale some years ago, when biosimilars represented a new concept with which few clinicians were familiar or supportive, this is no longer the case. We do not believe that marketing convenience justifies the conducting of unethical studies.

Finally, applications submitted to FDA must comply with the strict language of the biosimilars' law [8]. When Congress amended the law to create a legal pathway for the

\footnotetext{
1 Analytical and in vitro functional studies, human pharmacokinetic and immunogenicity studies; perhaps pharmacodynamic studies if there is a suitable pharmacodynamic marker.

2 Dr. Janet Woodcock, Deputy Commissioner and Chief Medical Officer, FDA, testified before the US Congress House Committee on Oversight and Government Reform on 'Follow-on Protein Products', March 26, 2007 (testimony at https://www.fda.gov/NewsEvents/Testi mony/ucm154070.htm). During the question-and-answer session, Dr. Woodcock stated that, in FDA experience, when biologics' sponsors use a comparability approach to justify manufacturing changes to biologics, clinical data are required in not more than $1-2 \%$ of cases, if that.
} 
approval of generic drugs (the Hatch-Waxman Amendments) [9], it was concerned that FDA's regulatory burden upon generic drug sponsors should be the minimum necessary to both encourage the use of the pathway and ensure the availability of safe and effective generic products. Therefore, after describing the data to be submitted in a generic drug application in very specific terms, Congress took the rare step of legally restraining a federal agency by adding the following statement to the law:

\section{The Secretary ${ }^{3}$ may not require that an abbreviated application contain information in addition to that required by clauses (i) through (viii).}

In creating the Biologics Price Competition and Innovation Act of 2009, it is evident that Congress had a similar intent, which is reflected in the language of the law describing the data to be submitted in an application for a biosimilar [10]:

(cc) a clinical study or studies (including the assessment of immunogenicity and pharmacokinetics or pharmacodynamics) that are sufficient to demonstrate safety, purity, and potency in 1 or more appropriate conditions of use for which the reference product is licensed and intended to be used and for which licensure is sought for the biological product [emphasis added]

As in Hatch-Waxman, the plain language of the law expresses Congress's intent that the development process for biosimilars should be as efficient as possible, such that the required clinical studies should not exceed those strictly required ("sufficient") to demonstrate biosimilarity. Since these data will vary, case by case, the law provides FDA the regulatory discretion to assess the necessity for clinical studies on the same basis and not require them routinely for all biosimilars. This is particularly necessary for efficacy studies, given their limited sensitivity to small differences in the structure and composition of the biosimilar candidate and its reference. As such, we believe that a careful assessment must be made by both sponsor and regulators as to the potential value of any clinical study before it is undertaken.

We commend Dr. Frapaise for his article and welcome other responses as we remind all interested parties that the purpose of scientifically justified abbreviation of biosimilars' development is to expand access to these transformational medicines for patients $[11,12]$.

\footnotetext{
3 The Secretary of Health and Human Services, as represented by FDA.
}

\section{Compliance with Ethical Standards}

Funding No funding was received for the preparation of this manuscript.

Conflict of interest C. J. Webster consulted for Sandoz US Inc. for a single mock FDA Advisory Committee for a single biosimilar product during 2017. G. R. Woollett has no conflicts of interest.

Open Access This article is distributed under the terms of the Creative Commons Attribution-NonCommercial 4.0 International License (http://creativecommons.org/licenses/by-nc/4.0/), which permits any noncommercial use, distribution, and reproduction in any medium, provided you give appropriate credit to the original author(s) and the source, provide a link to the Creative Commons license, and indicate if changes were made.

\section{References}

1. Frapaise F-X. The end of phase 3 clinical trials in biosimilars development? BioDrugs. 2018;32(4):319-24. https://doi. org/10.1007/s40259-018-0287-0.

2. Biopharmaceutical industry-sponsored clinical trials: impact on state economies. Pharmaceutical Research and Manufacturers of America (PhRMA); 2015. http://phrma-docs.phrma.org/sites /default/files/pdf/biopharmaceutical-industry-sponsored-clini cal-trials-impact-on-state-economies.pdf. Cited cost has been increased by $5 \%$ to account for real increase since publication of the report. Accessed 1 Aug 2018.

3. Sertkaya A, Birkenbach A, Berlind A, Eyraud J; Eastern Research Group, Inc. Examination of clinical trial costs and barriers for drug development. https://aspe.hhs.gov/report/examination-clini cal-trial-costs-and-barriers-drug-development. Accessed 1 Aug 2018.

4. ICH E6 guideline for good clinical practice: a trial should be initiated and continued only if the anticipated benefits justify the risks. http://www.ich.org/fileadmin/Public_Web_Site/ICH_Products/ Guidelines/Efficacy/E6/E6_R1_Guideline.pdf. Accessed 1 Aug 2018.

5. Vezér B, Buzás Z, Sebeszta M, Zrubka Z. Authorized manufacturing changes for therapeutic monoclonal antibodies (mAbs) in European Public Assessment Report (EPAR) documents. Curr Med Res Opin. 2016. https://doi.org/10.1185/03007 995.2016.1145579.

6. Schellekens H, Smolen JS, Dicato M, Rifkin RM. Safety and efficacy of biosimilars in oncology. Lancet Oncol. 2016;17:e502-9.

7. Christl L. Overview of the regulatory framework and FDA's guidance on the development and approval of biosimilar products in the US, 25 May 2017 (slide 32). https://www.fda.gov/downloads/ AdvisoryCommittees/CommitteesMeetingMaterials/Drugs/Oncol ogicDrugsAdvisoryCommittee/UCM561565.pdf. Accessed 1 Aug 2018.

8. The Biologics Price Competition and Innovation Act of 2009, (BPCIA), 42 USC 262(k). https://www.fda.gov/downloads/drugs /ucm216146.pdf. Accessed 1 Aug 2018.

9. Public Law 98-417. Amendments to the food, drug and cosmetic act at $\$ 505(\mathrm{j})$ and codified at $21 \mathrm{CFR} 314.94$. https://www.gpo. gov/fdsys/pkg/CFR-2012-title21-vol5/pdf/CFR-2012-title21-vol5sec314-94.pdf. Accessed 1 Aug 2018.

10. USC 262(k)(2)(A)(i). https://www.gpo.gov/fdsys/pkg/USCOD E-2010-title42/pdf/USCODE-2010-title42-chap6A-subchapIIpartF-subpart1-sec262.pdf. Accessed 1 Aug 2018. 
11. FDA Commissioner Scott Gottlieb, MD. Capturing the benefits of competition for patients. 2018. https://www.fda.gov/NewsEvents/ Speeches/ucm599833.htm. Accessed 1 Aug 2018.
12. Keynote address by Commissioner Gottlieb to the 2018 FDLI annual conference. 2018. https://www.fda.gov/NewsEvents/Speec hes/ucm606541.htm. Accessed 1 Aug 2018. 